\title{
Article
}

\section{"Tell me what they do to my body": A survey to find out what information people with learning disabilities want with their medications}

Fish, rebecca, Hatton, Christopher and Chauhan, Umesh

Available at https://clok.uclan.ac.uk/18553/

Fish, rebecca, Hatton, Christopher and Chauhan, Umesh orcid iconORCID: 0000-0002-0747-591X (2017) "Tell me what they do to my body": A survey to find out what information people with learning disabilities want with their medications. British Journal Of Learning Disabilities . ISSN 1354-4187

It is advisable to refer to the publisher's version if you intend to cite from the work.

For more information about UCLan's research in this area go to

http://www.uclan.ac.uk/researchgroups/ and search for <name of research Group>.

For information about Research generally at UCLan please go to http://www.uclan.ac.uk/research/

All outputs in CLoK are protected by Intellectual Property Rights law, including Copyright law. Copyright, IPR and Moral Rights for the works on this site are retained by the individual authors and/or other copyright owners. Terms and conditions for use of this material are defined in the policies page.

\section{CLoK}

Central Lancashire online Knowledge www.clok.uclan.ac.uk

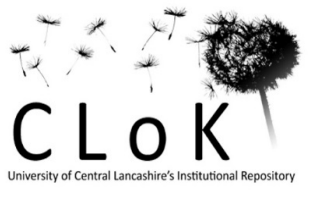




\section{"Tell me what they do to my body": A survey to find out what information people with learning disabilities want with their medications}

Dr Rebecca Fish, Centre for Disability Research, Department of Sociology, Lancaster University, UK Prof Chris Hatton, Centre for Disability Research, Faculty of Health and Medicine, Lancaster University, UK.

Dr Umesh Chauhan, Medical School, University of Central Lancashire, Preston, UK

\section{Accessible Summary}

- We gave a questionnaire to self-advocates who were attending a conference. The questionnaire asked them how they felt about the information they get with their medicine.

- $\quad$ Fifty eight people completed the questionnaire. Many of them said they did not get enough information about their medicine. Most people wanted easy-read leaflets and pictures.

- There are many different places to find easy-read information on the internet. We think they should be collected and checked. We also think that doctors and chemists need to spend more time with people to explain about medicines.

\section{Abstract}

Background: Previous research has found that people with learning disabilities are not given prescription information that is tailored to their needs. We wanted to find out people's information requirements.

Materials and Methods: A questionnaire was co-produced by the authors and consultants with learning disabilities. It asked them what information people received from their GP and pharmacist about medications. The questionnaire was circulated at a self-advocacy conference in the North of England. Fifty eight self-advocates completed the questionnaire.

Results: Information from GPs and pharmacists was mainly instructional, referring to when and how to take the medicine and dosage. Most respondents struggled to read the leaflets and remember verbal information. Many wanted the information in easy-read format, and some wanted pictures or diagrams as well. A key theme was that health professionals often talked only to carers or support workers rather than involving the patient directly, and some disclosed that they were not informed about side effects or alternative medications.

Conclusions: Health professionals should take time to discuss health issues and medication with the individual rather than only with carers. This could be facilitated by providing information in an accessible format. 


\section{Introduction}

There are clear health disparities between people with learning disabilities and the general population (Heslop et al., 2014, Emerson and Hatton, 2013), leading to concern among professionals about the health information they provide. People with learning disabilities are prescribed medication for psychological and medical conditions as well as for the reduction of challenging behaviour (Lewis et al., 2002). They experience higher rates of adverse health conditions such as epilepsy and neurological disorders, gastrointestinal disorders and psychiatric conditions as well as higher levels of preventable health issues (Krahn et al., 2006). Some of this disparity may be because they are not getting the correct information about medication, healthy living or self-screening (Krahn et al., 2006), and furthermore they may experience poorer access to quality primary care due to lack of reasonable adjustments which take into account people's needs (Balogh et al., 2010, Alborz et al., 2005).

It has been found that education level and cognitive functions such as memory and conceptualisation are related to medication compliance in psychiatric services (Ruscher et al., 1997, Jeste et al., 2003). Often, 'health literacy' of patients is referred to as the problem (Wolf et al., 2006), however it has been argued that this can be addressed by reducing the use of jargon and understanding the communication needs of patients (Shepard, 2016).

In a review of the literature about medication/prescription information and the perspectives of people with learning disabilities, we found a small number of research studies. Among them were Arscott et al (2000), who interviewed 30 people with learning disabilities about their medication. They found that $70 \%$ of adults with learning disabilities took psychotropic medication, $66.7 \%$ took non psychotropic medication and $26.6 \%$ of their participants were prescribed 4 or more medications regularly. In terms of information, they found that their participants had limited knowledge about side-effects, alternatives to the medicine they were taking and contra-indications. Arscott et al argue that people are not given enough information about their medicine, and that information is not accessible enough.

Heslop et al. (2005) found their participants to be similarly ill-informed. They interviewed 21 people with learning disabilities, their carers and prescribers. They found that few people were fully advised about why they were taking their medication and the potential adverse effects. Most of the information had been given to carers, who knew how to administer medicines but did not know why they had been prescribed or the implications. People felt that they had little or no choice about taking the medication. Heslop et al recommended that prescribers spend time to explain key facts and provide accessible and up-to-date information which is tailored to the patient's needs, and that training should be provided for carers. 
A key theme in the literature is that people were given inappropriate information not tailored to their needs. For example, a National Patient Safety Agency (2004) study with 45 participants with learning disabilities found that medication information was inaccessible; the participants in this study would have preferred information with pictures or in an audio format. People said that they often identified their tablets by colour, something that was flagged up in the report as potentially dangerous, as different pills can look similar to each other and a medication's appearance can change over time.

Research has found that people with learning disabilities also lack knowledge about psychotropic medications that they are prescribed. For example, Strydom et al. (2001) gave a questionnaire to 21 people with learning disabilities who were prescribed antipsychotic medication; 22\% did not know why they were taking the medication, $48 \%$ could not read the label, $38 \%$ did not know any side effects, and $52 \%$ were not aware of any contraindications. Twenty people said they would have liked a readable leaflet. Participants wanted more information about indications, contra-indications and side effects. Strydom et al suggest that people with learning disabilities are unlikely to seek information about their medications and it is therefore the responsibility of health professionals to make such information readily available and understandable. Even if people with learning disabilities do possess adequate information, they may experience difficulties in communicating side-effects of their medication and may find it hard to report adverse effects such as blurred vision or feeling dizzy.

Research investigating pharmacist services reveals some of the information barriers. The Disability Partnership (2016) gathered in-depth questionnaire data about medication and pharmacy visits from 103 people with learning disabilities. They found that respondents visited their pharmacist once a month on average and $30 \%$ wanted their pharmacist to be more patient. Fifteen percent of respondents stated that they did not know why they took their medication. They conclude that a number of barriers to positive experiences exist, such as access to information, clear communication and explanation of the purpose of medicines. They advise that there is significant room for improvement in order to make pharmacy services for disabled people an empowering experience in relation to managing their health.

Similarly, Jubraj et al (2016b) explored people's experiences of pharmacies in a focus group with people with learning disabilities. They found that the focus group members in their study, despite regularly taking medicines, were unclear about why they needed them and how they helped. They explained that pharmacists often spoke to their parents or carers during consultations instead of them. All were unaware that they could ask the pharmacist themselves for information about their 
medicines. Group members said they would like the pharmacist to talk to them directly and give them more accessible information about their medicines.

This existing literature shows that people with learning disabilities are not getting enough information about their medication from either their GP or pharmacists. In particular, more information is needed about the function of the medicine as well as risk factors and contraindications. Furthermore, health professionals are not involving patients themselves in consultations enough, preferring to discuss with carers or family members. Health outcomes are better when patients take a more participatory role in decisions about their health (Trummer et al., 2006), but without making sure that patients have the correct knowledge to make decisions, it is impossible to assume their consent to treatment.

Each of the studies outlined above focusses on a particular area of prescribing. None of the studies asks participants where they get the most helpful information from and what format they would prefer. This research study aimed to explore these questions using a small-scale questionnaire study.

\section{Policy}

There are important national guidelines in the UK on how communication should occur with people with learning disabilities. The Mental Health Act (1983) makes it clear that people should be informed about side effects of medication as well as alternatives. Further, NICE guidance (2012, 2009) mentions consent, capacity and decision-making, advising that professionals should assess the person's capacity to make decisions throughout assessment, care and treatment for any health problem on a decision-by-decision basis, in accordance with the Mental Capacity Act (2005). People should be helped to decisions by ensuring that their communication needs are met and (if appropriate) involving a family member, carer, care worker or other individual familiar with the person's communication abilities. The requirement for service providers to make "reasonable adjustments" to their provision, including information they offer about their services, is included in the 2010 Equality Act (Equality Act, 2010).

The NHS England Accessible Information Standard (2016) came into force in England on $31^{\text {st }}$ July 2016. The Standard specifies that it is the responsibility of services to make understandable information available to everyone. The principles for health services are as follows:

1. Ask: find out if an individual has any communication or information needs relating to an impairment or sensory loss and if so what they are. This must be done 'proactively and opportunistically' using professional judgment. This may include using guidance questions to find out about any learning disability, as detailed in Glover and Emerson (2012). 
2. Record: record those needs in a clear, unambiguous and standardised way in electronic and / or paper based record. Information needs should be recorded rather than impairment or condition.

3. Alert / flag / highlight: ensure that recorded needs are 'highly visible' whenever the individual's record is accessed, and prompt for action.

4. Share: include information about individuals' information or communication needs as part of existing data sharing processes (and in line with existing information governance frameworks).

5. Act: take steps to ensure that individuals receive information which they can access and understand, and receive communication support if they need it.

Although this act only relates to England, it should be considered good practice for all health providers to follow this guidance. The Equality Act (UK) and the Accessible Information Standard make it clear that it is the responsibility of the organisation and its staff to make information understandable in order that patients make informed decisions about their care.

It is envisaged that the findings from the present study will be helpful to services when they are planning how to implement these policy goals, in terms of people's information requirements and the format of resources to use.

\section{Method}

This study was funded by East Lancashire Clinical Commissioning Group (CCG). Ethical approval was granted by the ethics committee at Lancaster University Faculty of Health and Medicine and was determined to be service evaluation/improvement by the NHS Research Ethics Committee. The aim of the study was to gauge the level of information currently being provided, and the requirements of people with learning disabilities for more information related to their medication. The research questions for this study were:

1. What prescription and medication information do people with learning disabilities currently receive from their GP?

2. What information do they receive from their pharmacist?

3. How helpful is this information?

4. What other information is required and how should it be presented?

The researchers collaborated with the North West Training and Development Team (NWTDT) and Pathways Associates to discuss the research questions with them. NWTDT and Pathways Associates are not for profit organisations who work with self-advocacy group members to provide consultancy services. They discussed the research objectives with their consultant members and the researchers 
and created an easy-read questionnaire that asked the following questions (accompanied by pictures):

- What information are you given when you get medicine from the doctor?

- Is it useful?

- What else could the doctor do to help you understand your medicine?

- What information are you given when you get your medicine from the chemist?

- What other support would help people to understand their medicine?

The pictures were simple, line drawn black and white, depicting people and objects such as medicine bottles and pill blister packs.

This questionnaire was circulated to all self-advocates at the North West Self-Advocacy conference which was held in Blackpool in February 2016 and is organised by NWTDT and Pathways Associates. The delegates were asked to complete the questionnaires alone or with support from their assistant or family members.

Fifty eight questionnaires were returned. This represents approximately $48 \%$ of the 120 selfadvocates who attended the conference. This may have some relevance to the type of data obtained; perhaps only those who were above a particular threshold of literacy agreed to complete a questionnaire. The questionnaires were anonymous, no names were collected or recorded.

The results were organised into themes, with a frequency count to show how many responses reported the same issue. In the results section below, we use tables to show the frequency count and provide an example quote to illustrate the theme.

\section{Results}

From the questionnaire responses, it was clear that people had experience of visiting and obtaining medications from both GP surgeries and pharmacists. Most of the questionnaires were fully completed and people often provided multiple points in each section. Each of the following tables shows the groups of responses and the amount received. Example comments from the completed questionnaires are provided.

Fifty five percent of people ( $n=32$ ) said that they got helpful information from their GP; Table 1 shows in more detail what information they received. Out of those who answered that the information was helpful, most of the information they received was instructional, such as when to take the medicine and for how long. Some of these participants reported that their GP took time to explain about the medicine and show them how to take it.

Table 1: Helpful information received from GP 


\begin{tabular}{lcl}
\hline Response & Frequency & \multicolumn{1}{c}{ Example comment } \\
$\begin{array}{l}\text { When to take medicine / how often / } \\
\text { for how long }\end{array}$ & 11 & $\begin{array}{l}\text { '3 Times daily, for asthma. Written and } \\
\text { verbal.' }\end{array}$ \\
\hline $\begin{array}{l}\text { Took time to explain about medicine } \\
\text { / answered questions }\end{array}$ & 7 & $\begin{array}{l}\text { 'Told everything about my medicine. Does } \\
\text { explain to me.' } \\
\text { 'What the medicine is called and what it is } \\
\text { used for.' }\end{array}$ \\
\hline What the medicine is used for & 5 & $\begin{array}{l}\text { 'I have a good doctor who will tell me what } \\
\text { the medicine is for and will answer any } \\
\text { questions I have.' }\end{array}$ \\
\hline $\begin{array}{l}\text { How the medicine works and what it } \\
\text { does }\end{array}$ & 4 & $\begin{array}{l}\text { 'My doctor tells me statins are for my } \\
\text { cholesterol.' }\end{array}$ \\
\hline How to take the medicine & 3 & $\begin{array}{l}\text { 'Just to take my inhalers, brown one twice } \\
\text { in the morning and night, blue one when } \\
\text { I'm wheezing.' }\end{array}$ \\
\hline When to get next prescription & 2 & $\begin{array}{l}\text { 'They tell me when to pick my next } \\
\text { prescription up and what they are for.' }\end{array}$ \\
\hline Showed me how to take it & 2 & $\begin{array}{l}\text { 'Showed how to use the medication. Tested } \\
\text { condition for a while then diagnosed. } \\
\text { Verbal.' }\end{array}$ \\
\hline Dosage & 2 & $\begin{array}{l}\text { 'The information you are given is the sort of } \\
\text { tablets they put you on and how many } \\
\text { times a day to take them.' }\end{array}$ \\
\hline
\end{tabular}

Overall $29 \%$ of participants $(n=17)$ said the information they received was not helpful. Table 2 shows the reasons people gave for this. The most frequent themes were that the information was not accessible to them and they were only given basic information. Some people reported that information was only given to their carer and they were not involved in the discussions.

Table 2: Reasons why information given by GP is not helpful

\begin{tabular}{|c|c|c|}
\hline Response & Frequency & Example comment \\
\hline $\begin{array}{l}\text { I can't read or write / writing too } \\
\text { small and no pictures }\end{array}$ & 4 & $\begin{array}{l}\text { 'He gives us the medicine. I can't read or } \\
\text { write so then don't understand what's on it. } \\
\text { He sometimes tells me but I don't always } \\
\text { remember what's been said so ask friends } \\
\text { or People First.' }\end{array}$ \\
\hline $\begin{array}{l}\text { I am only told when to take it / how } \\
\text { to take it }\end{array}$ & 4 & $\begin{array}{l}\text { 'How to take it and for how long. If no } \\
\text { better come back in two weeks.' }\end{array}$ \\
\hline Just verbal instructions & 3 & $\begin{array}{l}\text { 'Not much write the prescription out. } \\
\text { Doctor says how often to take it.' }\end{array}$ \\
\hline $\begin{array}{l}\text { Only told what the medicine is } \\
\text { called }\end{array}$ & 2 & 'Just what I take.' \\
\hline Instructions are given to my carer & 2 & 'It's given to my dad not me.' \\
\hline No information given & 2 & 'I just get a prescription.' \\
\hline
\end{tabular}

Table 3 shows what information people said they received from their pharmacist. Twenty four percent of respondents $(n=14)$ reported receiving no information at all. The information people 
reportedly received was instructional, such as dosage and when to take the medicine. Five respondents reported that the pharmacist gave information to their carer but not to them. Some people reported that the information was not accessible or was given verbally only.

Table 3: Information received from pharmacist

\begin{tabular}{|c|c|}
\hline Response & Frequency \\
\hline No information & 14 \\
\hline \multicolumn{2}{|l|}{ Paper Information } \\
\hline - Dosage & 8 \\
\hline - Inaccessible leaflet & 8 \\
\hline - When / how often to take medicine & 7 \\
\hline - Different names for the same medicine is confusing & 2 \\
\hline - How to store the medicine & 1 \\
\hline - Given a phone number & 1 \\
\hline \multicolumn{2}{|l|}{ Face-to-face } \\
\hline - Given verbal information & 4 \\
\hline - When to come back / how long medicine will last & 3 \\
\hline - How to take medicine & 3 \\
\hline - Mentioned a side-effect & 1 \\
\hline \multicolumn{2}{|l|}{ Other } \\
\hline - They speak to my carer not to me & 5 \\
\hline - Information is on computer, not accessible to me & 2 \\
\hline
\end{tabular}

Table 4 shows all the suggestions that people gave for change, incorporating the answers to both questions: 'What else could the doctor do to help you understand your medicine?' And 'What other support would help people to understand their medicine?' Sixty six percent of people $(n=38)$ wanted an easy read leaflet and $17 \%(n=10)$ wanted pictures or diagrams. Seven percent $(n=4)$ reported that they wanted information about side effects and risks so they could make a choice about different medicines. Some participants stated that they wanted their carers or family to be involved, but would prefer that the health professionals discussed the issues with them as the patient.

Table 4: suggestions for change

\begin{tabular}{|ccl|}
\hline Response & Frequency & \multicolumn{1}{c|}{ Example } \\
\hline Paper Information & \multicolumn{2}{c|}{$\begin{array}{l}\text { 'Information that's easy to understand for } \\
\text { no jargon / greater detail } \\
\text { everyone. Large print easy read instructions. } \\
\text { Pictures.' }\end{array}$} \\
\hline - Pictures / diagrams & 38 & $\begin{array}{l}\text { 'Talk to me easier. Giving me pictures of } \\
\text { when to take the tablets e.g. picture of sun } \\
\text { = sunrise am } \times \text { 2 tablets. Give me easy read } \\
\text { info about what it is for.' }\end{array}$ \\
\hline $\begin{array}{l}\text { Safety info / how not to } \\
\text { overdose / what happens if } \\
\text { not taken }\end{array}$ & 6 & $\begin{array}{l}\text { 'Could help to understand what may } \\
\text { happen if not taken or more than dose } \\
\text { taken, to help you.' }\end{array}$ \\
\hline
\end{tabular}




\begin{tabular}{|c|c|c|c|}
\hline & $\begin{array}{l}\text { Information about side } \\
\text { effects / risks }\end{array}$ & 4 & $\begin{array}{l}\text { 'Actually explain why you are taking it and } \\
\text { what it does and what it is for. Say what I } \\
\text { might expect (side effects).' }\end{array}$ \\
\hline$\bullet$ & $\begin{array}{l}\text { Photos / videos of how to } \\
\text { take it }\end{array}$ & 3 & $\begin{array}{l}\text { 'Written down info and video on how to } \\
\text { take it.' }\end{array}$ \\
\hline$\bullet$ & Telephone helpline & 2 & $\begin{array}{l}\text { 'A telephone helpline with simple audio } \\
\text { information about medicine and what it } \\
\text { does.' }\end{array}$ \\
\hline & $\begin{array}{l}\text { Information about how to } \\
\text { look after ourselves to avoid } \\
\text { medicine }\end{array}$ & 1 & $\begin{array}{l}\text { 'How to look after ourselves so we don't } \\
\text { have to use our medicine for a long time / } \\
\text { reduce amount.' }\end{array}$ \\
\hline \multicolumn{4}{|c|}{ Face-to-face } \\
\hline & $\begin{array}{l}\text { Listen to patient / take time } \\
\text { to explain and answer } \\
\text { questions }\end{array}$ & 11 & $\begin{array}{l}\text { 'I get upset. The doctor needs to slow down } \\
\text { and tell me what is happening. Then I will } \\
\text { feel better.' }\end{array}$ \\
\hline • & $\begin{array}{l}\text { Support workers / families } \\
\text { involved and informed }\end{array}$ & 10 & $\begin{array}{l}\text { 'Support worker/parent explaining again } \\
\text { about meds in a comfortable relaxed } \\
\text { environment and ask if any questions.' }\end{array}$ \\
\hline$\bullet$ & $\begin{array}{l}\text { Verbal explanations with no } \\
\text { difficult words }\end{array}$ & 9 & $\begin{array}{l}\text { 'Any info in a verbal equivalent of easy read, } \\
\text { plain English would help.' }\end{array}$ \\
\hline$\bullet$ & Explain why I need to take it & 8 & $\begin{array}{l}\text { 'Easy read and simple explanation (needs to } \\
\text { be written down, I don't always get it when } \\
\text { they just say it). What I need to take, when I } \\
\text { need to take it and why I am taking it.' }\end{array}$ \\
\hline$\bullet$ & $\begin{array}{l}\text { Explain how the medicine } \\
\text { works }\end{array}$ & 5 & $\begin{array}{l}\text { 'To talk about it a bit longer. Tell me what } \\
\text { they do to my body.' }\end{array}$ \\
\hline & $\begin{array}{l}\text { Aids such as hearing loop / } \\
\text { braille / sign language / } \\
\text { interpreter }\end{array}$ & 5 & $\begin{array}{l}\text { 'If you are buying medicine over the counter } \\
\text { for a cold or diarrhoea if you need this they } \\
\text { could explain what medicine is best for you } \\
\text { they could also have a hearing loop for deaf } \\
\text { people or provide braille for people with } \\
\text { poor sight.' }\end{array}$ \\
\hline & $\begin{array}{l}\text { Talk to patient rather than } \\
\text { support / carers }\end{array}$ & 4 & $\begin{array}{l}\text { 'Make words bigger and easy-read. Spend } \\
\text { time explaining things to me and not the } \\
\text { support.' }\end{array}$ \\
\hline & $\begin{array}{l}\text { Explain about alternative } \\
\text { medicines }\end{array}$ & 3 & $\begin{array}{l}\text { 'Give me an easy read information sheet: is } \\
\text { there something else I can take instead?' }\end{array}$ \\
\hline \multicolumn{4}{|c|}{ Other } \\
\hline & $\begin{array}{l}\text { Regular reviews and health } \\
\text { checks }\end{array}$ & 5 & $\begin{array}{l}\text { 'Your doctor could tell you why you need } \\
\text { your medication. He could send you for a } \\
\text { medical review and take blood tests.' }\end{array}$ \\
\hline & $\begin{array}{l}\text { Mobile alerts / special alarm } \\
\text { as reminder / timetable }\end{array}$ & 4 & $\begin{array}{l}\text { 'Talk to you about it in words you } \\
\text { understand and give you a clear timetable } \\
\text { so you know when to see them!' }\end{array}$ \\
\hline & $\begin{array}{l}\text { Label / container with space } \\
\text { to write on }\end{array}$ & 2 & $\begin{array}{l}\text { 'Tell me why I'm taking it. Make sure the } \\
\text { label on the bottle says how to take it. } \\
\text { Saying 'as discussed' doesn't help.' }\end{array}$ \\
\hline
\end{tabular}




\section{Discussion}

The results of this study suggest that people are generally not receiving information that they can understand and retain. People were only being given basic information about when and how to take the medicine and not offered information about side effects or contraindications. Participants had many recommendations about the information that would help them to understand how to take medications, such as easy-read leaflets and pictures / diagrams or videos. They also had advice about other things that health professionals could do, such as offer advice on healthy living and alternative medications. The participants often wanted their carers or family members to be informed about their medications, but a key theme from the results was that they wanted to be involved directly in the consultations.

Most of the respondents recommended easy-read information and information with pictures. Easy read leaflets or labels have been found to improve knowledge of health information (psychology, primary care and prescription information) in some studies (Hurtado et al., 2014, Ziviani et al., 2004, Wolf et al., 2006). However, in a randomized controlled trial of psychotropic medication information leaflets for people with learning disabilities, Strydom and Hall (2001) found that the leaflets did not significantly improve any aspect of medication knowledge. They proposed that this may have been due to health professionals relying on the leaflets as the only information source without offering sufficient verbal information. Further, accessible communication depends on the individual; easyread information is not always accessible to all people with learning disabilities and it is important to take individual needs into account. Some easy-read material may leave out important details in the quest for simplicity, such as contra-indications or the patient's right to opt out of treatment (Chinn and Homeyard, 2016). Alternatives to easy-read leaflets are visual or audio formats, however some of our participants reported that they found it difficult to remember verbal information. Therefore, we propose that offering easy-read and pictorial information to take home along with signposts to other mediums (such as apps, DVDs etc) should be combined with verbal information in a consultation that is tailored to the person. Adapted health information has a better chance of making an impact when it is tailored to an individual's individual requirements (Chinn and Homeyard, 2016). Further, it is important that the resources should be co-produced with people with learning disabilities who are more likely to have experienced the insufficiency of health information as described in this study and the wider literature (Ward and Townsley, 2005). Strydom and Hall (2001) advised that rather than excluding people with learning disabilities from the resources available, carers and health professionals should assist them to use the resources and help them to align new knowledge with previous knowledge. This suggests that appointment windows should be extended in order that there is time to do this (Jubraj et al., 2016a). We agree with Heslop 
et al. (2005), who recommend that professionals have time to spend on key facts, having accessible information available which is kept up-to-date, and training about medication for carers.

Most of the participants in the current study did not recall receiving enough information about their medication, including side effects. It is possible that health professionals do not want to provide an overwhelming amount of information. McGrath (1999) reported that prescribers preferred two-way interactions focusing on the specific needs of the patient, rather than simply disseminating more and more information about the prescription. However, the prescribers in McGrath's study tended to weigh up the benefits of providing full drug information against the potential of anxiety about possible side-effects, suggesting that paternalistic decisions are made about what information to include with all patients. Further, Ziegler et al. (2001) found that people without learning disabilities generally want more information from their prescribers, with those with lower levels of education requiring more than others. Llewellyn-Jones et al (2001) revealed that few general patients pose questions to their psychiatrist, reflecting the difficulties that patients had in discussing their symptoms and their medication. They concluded that patients may fear being judged if they say too much or they may be worried about the trivialisation of their concerns. This illustrates the need for objective information as well as tailored interaction in order to support informed consent.

The question of who provides this information is an important consideration. In the present study, most of the people said they received information from their GP. People with learning disabilities are often invisible to pharmacists (Flood and Henman, 2010) as carers or staff often pick up the medications. However, some of our respondents pointed out that the GP and pharmacists talked to their carer or family member and not them, even when they were present. Participants in other studies also have commented on this (Jubraj et al., 2016b, The Disability Partnership, 2016). We argue that pharmacy consultations should be in-depth and tailored to the person's communication style and ability (Dickinson et al., 2013). Furthermore, GPs, nurses and pharmacists should work together to share information about patients' requirements and provide person centred care (Blasi et al., 2006).

The respondents in this study reported that they wanted access to resources that they could understand and refer back to. In terms of access to resources, there have been a number of movements towards providing assistance with reasonable adjustments. For example:

- The Learning Disabilities Observatory surveyed NHS trusts to find out what is provided (Hatton et al., 2011) and from this, Turner and Robinson (2011) produced resources for professionals and service-users about their right to expect reasonable adjustments. 
- The organisation Change have worked with self-advocates to produce an easy-read guide to the Accessible Information Standard (Change, 2016).

- The Medication Matters project (Norah Fry Centre, 2004) produced:

- a checklist of things to ask the doctor about medication which can be used by people with learning difficulties, their families and carers,

- a booklet for people with learning difficulties, their families or carers where they can record information about their medications,

- an interactive decision making tool for people with learning difficulties to help them make informed choices about taking the medications they are prescribed

- a guide for prescribers of psychotropic medications to things they should consider when issuing a prescription for psychotropic medication to people with learning difficulties

0 and a list of sources of information about medications.

- Some agencies have designed accessible and easy read proformas and leaflets which cover health issues (Norah Fry Centre, 2004), videos about health (easyhealth.org.uk) and easyread psychoactive medication leaflets and audio downloads (birmingham.ac.uk/research/activity/ld-medication-guide/index.aspx and cwp.nhs.uk) many of which are collated in one BILD website (bild.org.uk/easyread/).

- Others have developed decision making tools for patients (The Disability Partnership, 2016) and communication aid resources which can be used two-way to discuss health information (Dodd and Brunker, 1999, Heslop et al., 2004).

- Creative strategies have been devised to improve two way communication such as the use of Health Passports (Disability Partnership, 2016), training service users to evaluate and review health services (Campbell and Martin, 2010) and employing service users to train pharmacists in how to communicate effectively (Donnelly, 2013).

- Jubraj et al. (2016b) recommend the use of 'My Medication Passport' as focus groups in their study felt that this was a useful tool.

These resources are all designed to help with accessible information provision to people with learning disabilities. Despite this wealth of available resources, the participants in the present study were not getting the information they needed. This could be due to lack of knowledge or awareness of the resources, or a lack of a centralised, approved space where they are stored. Further, most of 
the easy-read information available does not concern specific medications and this is what this study highlights as a crucial gap.

There are limitations to this study. It should be noted that the sample of self-advocates is not representative of people with learning disabilities; it is a convenience sample only. A sample taken from a group of self-advocates may have a higher ability and/or skill level than a sample of people with learning disabilities taken from the general population. Further, the people who chose to complete a questionnaire may have been those with higher literacy levels than others at the conference. Therefore, the results of this study should not be taken as generaliseable.

\section{Conclusion}

A key finding of this study, consistent with other studies, is that health professionals tend to talk to carers or family members rather than the individual themselves. This could be due to lack of skills and knowledge and could be addressed through training for GPs and pharmacists on eliciting and providing information to individuals with communication needs. The diverse responses and recommendations we received demonstrate the wide range of accessibility requirements; health professionals should develop skills and systems to tailor their information to the person and be willing to provide information in more than one format (such as verbal and easy-read).

Another key finding was that not all professionals spend the time to explain conditions and medications to people with learning disabilities. We recommend that extra appointment time should be allotted to working with people with accessibility needs, that professionals should spend the time early on to get to know the individual and their requirements, and this will compensate in later appointments.

This study also demonstrates the lack of knowledge about available resources for people with learning disabilities. Future research should focus on the implications of not being provided with health information that is accessible, in particular the issue of polypharmacy and the difficulties of retaining information and knowledge regarding multiple medications. Future research could explore the viability of providing a centralised system, connected electronically to GP and pharmacist information systems. This sort of resource, along with person centred consultations with both GP and pharmacy staff, would allow greater access to the information people need to make informed decisions about their medications, and better knowledge of how to use them.

\section{Acknowledgments}

The authors would like to thank Professor Bob Gates and the anonymous reviewers for their comprehensive and helpful comments on earlier drafts of this paper. The authors would also like to thank NWTDT and Pathways Associates for their input into this project. 


\section{References}

ALBORZ, A., MCNALLY, R. \& GLENDINNING, C. 2005. Access to health care for people with learning disabilities in the UK: mapping the issues and reviewing the evidence. Journal of Health Services Research \& Policy, 10, 173-182.

ARSCOTT, K., STENFERT KROESE, B. \& DAGNAN, D. 2000. A study of the knowledge that people with intellectual disabilities have of their prescribed medication. Journal of Applied Research in Intellectual Disabilities, 13, 90-99.

BALOGH, R., BROWNELL, M., OUELLETTE-KUNTZ, H. \& COLANTONIO, A. 2010. Hospitalisation rates for ambulatory care sensitive conditions for persons with and without an intellectual disability-a population perspective. Journal of Intellectual Disability Research, 54, 820-832.

BLASI, A., KENDALL, S. \& SPARK, M. J. 2006. Perspectives on the role of the community pharmacist in the provision of healthcare to people with intellectual disabilities: exploration of the barriers and solutions. International Journal of Pharmacy Practice, 14, 263-269.

CAMPBELL, M. \& MARTIN, M. 2010. Reducing health inequalities in Scotland: the involvement of people with learning disabilities as national health service reviewers. British Journal of Learning Disabilities, 38, 49-58.

CHANGE 2016. Your Rights Under The Accessible Information Standard. Available at changepeople.org (Accessed 18 January 2017).

CHINN, D. \& HOMEYARD, C. 2016. Easy read and accessible information for people with intellectual disabilities: Is it worth it? A meta-narrative literature review. Health Expectations.

DEPARTMENT OF HEALTH 2005. Mental Capacity Act. London: HMSO.

DICKINSON, R., HAMROSI, K., KNAPP, P., ASLANI, P., SOWTER, J., KRASS, I. \& RAYNOR, D. K. 2013. Suits you? A qualitative study exploring preferences regarding the tailoring of consumer medicines information. International Journal of Pharmacy Practice, 21, 207-215.

DODD, K. \& BRUNKER, J. 1999. 'Feeling poorly': report of a pilot study aimed to increase the ability of people with learning disabilities to understand and communicate about physical illness. British Journal of Learning Disabilities, 27, 10-15.

DONNELLY, V. 2013. How people with learning disabilities can help train professionals: Victoria Donnelly describes the reasonable adjustments pharmacists should make to ensure service users do not over use medications. Learning Disability Practice, 16, 24-26.

EMERSON, E. \& HATTON, C. 2013. Health inequalities and people with intellectual disabilities, Cambridge University Press.

EQUALITY ACT 2010. NEED TO KNOW. A summary guide for public sector organisations. Government Equalities Office London: HM Government.

FLOOD, B. \& HENMAN, M. 2010. An invisible profession: Pharmacists and the population with intellectual disability. Irish Pharmacy Journal, 88, 170.

GLOVER, G. \& EMERSON, E. 2012. Have you got a learning disability? Asking the question and recording the answer for NHS healthcare providers. Improving Health \& Lives: Learning Disabilities Public Health Observatory, Durham.

HATTON, C., ROBERTS, H. \& BAINES, S. 2011. Reasonable adjustments for people with learning disabilities in England 2010: A national survey of NHS Trusts. Durham: Improving Health \& Lives: Learning Disabilities Observatory.

HESLOP, P., BLAIR, P. S., FLEMING, P., HOGHTON, M., MARRIOTT, A. \& RUSS, L. 2014. The Confidential Inquiry into premature deaths of people with intellectual disabilities in the UK: a population-based study. The Lancet, 383, 889-895.

HESLOP, P., FOLKES, L. \& RODGERS, J. 2004. Why medication matters. Learning Disability Practice, 7, 10-12.

HESLOP, P., FOLKES, L. \& RODGERS, J. 2005. The knowledge people with learning disabilities and their carers have about psychotropic medication. Tizard Learning Disability Review, 10, 10 18. 
HURTADO, B., JONES, L. \& BURNISTON, F. 2014. Is easy read information really easier to read? Journal of Intellectual Disability Research, 58, 822-829.

JESTE, S. D., PATTERSON, T. L., PALMER, B. W., DOLDER, C. R., GOLDMAN, S. \& JESTE, D. V. 2003. Cognitive predictors of medication adherence among middle-aged and older outpatients with schizophrenia. Schizophrenia research, 63, 49-58.

JUBRAJ, B., BARNETT, N. L., GRIMES, L., VARIA, S., CHATER, A. \& AUYEUNG, V. 2016a. Why we should understand the patient experience: clinical empathy and medicines optimisation. International Journal of Pharmacy Practice.

JUBRAJ, B., DEAKIN, A., MILLS, S. \& GRIMES, L. 2016b. Pharmacy consultations with patients with learning disabilities. The Pharmaceutical Journal, Vol 296, No 7885,.

KRAHN, G. L., HAMMOND, L. \& TURNER, A. 2006. A cascade of disparities: health and health care access for people with intellectual disabilities. Mental retardation and developmental disabilities research reviews, 12, 70-82.

LEWIS, M. A., LEWIS, C. E., LEAKE, B., KING, B. H. \& LINDEMANN, R. 2002. The quality of health care for adults with developmental disabilities. Public health reports, 117, 174.

LLEWELLYN-JONES, S., JONES, G. \& DONNELLY, P. 2001. Questions patients ask psychiatrists. The Psychiatrist, 25, 21-24.

MCGRATH, J. M. 1999. Physicians' perspectives on communicating prescription drug information. Qualitative Health Research, 9, 731-745.

NATIONAL INSTITUTE FOR CLINICAL EXCELLENCE 2012. Patient experience in adult NHS services: improving the experience of care for people using adult NHS services. NICE guidance, Clinical guideline [CG138]

NATIONAL PATIENT SAFETY AGENCY 2004. Listening to people with learning difficulties and family carers talk about patient safety. In: NPSA (ed.).

NORAH FRY CENTRE. 2004. Medication Matters [Online]. Bristol University. [Accessed 17/01/2017].

NUNES, V., NEILSON, J., O'FLYNN, N., CALVERT, N., KUNTZE, S., SMITHSON, H., BENSON, J., BLAIR, J., BOWSER, A. \& CLYNE, W. 2009. Medicines Adherence: involving patients in decisions about prescribed medicines and supporting adherence. Developed by the National Collaborating Centre for Primary Care, NICE: National Institute for Health and Clinical Excellence, London, UK.

RUSCHER, S. M., DE WIT, R. \& MAZMANIAN, D. 1997. Psychiatric patients' attitudes about medication and factors affecting noncompliance. Psychiatric services (Washington, DC), 48, 82-85.

SHEPARD, K. 2016. Health literacy can be a matter of life or death. The Conversation, https://theconversation.com/health-literacy-can-be-a-matter-of-life-or-death-67469 accessed 19/06/2017.

STRYDOM, A., FORSTER, M., WILKIE, B., EDWARDS, C. \& HALL, I. 2001. Patient information leaflets for people with learning disabilities who take psychiatric medication. British Journal of Learning Disabilities, 29, 72-76.

STRYDOM, A. \& HALL, I. 2001. Randomized trial of psychotropic medication information leaflets for people with intellectual disability. Journal of Intellectual Disability Research, 45, 146-151.

THE DISABILITY PARTNERSHIP 2016. Evaluation Report of the 2015-16

Mencap-led Pharmacy Project. Available at https://www.mencap.org.uk/pharmacy-project (Accessed 18 January 2017).

TRUMMER, U. F., MUELLER, U. O., NOWAK, P., STIDL, T. \& PELIKAN, J. M. 2006. Does physicianpatient communication that aims at empowering patients improve clinical outcome?: A case study. Patient Education and Counseling, 61, 299-306.

TURNER, S. \& ROBINSON, C. 2011. Reasonable adjustments for people with learning disabilities: implications and actions for commissioners and providers of health care. Improving Health and Lives, Stockton on Tees. 
WARD, L. \& TOWNSLEY, R. 2005. 'It's about a dialogue...'1 Working with people with learning difficulties to develop accessible information. British Journal of Learning Disabilities, 33, 5964.

WOLF, M. S., DAVIS, T. C., TILSON, H. H., BASS III, P. F. \& PARKER, R. M. 2006. Misunderstanding of prescription drug warning labels among patients with low literacy. American Journal of Health-System Pharmacy, 63.

ZIEGLER, D. K., MOSIER, M. C., BUENAVER, M. \& OKUYEMI, K. 2001. How much information about adverse effects of medication do patients want from physicians? Archives of internal medicine, 161, 706-713.

ZIVIANI, J., LENNOX, N., ALLISON, H., LYONS, M. \& DEL MAR, C. 2004. Meeting in the middle: improving communication in primary health care consultations with people with an intellectual disability. Journal of Intellectual and Developmental Disability, 29, 211-225. 